\title{
BiR KÜLTÜN ÖZELLIKLERI: TÜRKLERDE SU KÜLTÜ
}

\author{
Characteristics of a Cult: Water Cult in Turks
}

Hüseyin UÇAR*

\section{ÖZET}

Dünyadaki muhtelif kültürlerin, doğal yaşamın vazgeçilmezi olan su öğesine yükledikleri anlamlar, suyun zaman içerisinde ilahi bir özellik kazanmasına ve "kült" olarak anılmasına sebep olmuştur. Türk kültüründeki uygulamalara baktığımızda da bu durum geçerliliğini korumaktadır. Su Kültü, özellikle İslamiyet öncesi Türk topluluklarının kutsallık atfettikleri nesneler arasında önemli bir yere sahiptir. Türkler nehir, göl, deniz, akarsu, bataklık, ırmak, çay gibi su kaynaklarının özel güçleri olduğuna ve içlerinde bir ruh barındırdıklarına inanmış, çeşitli şekillerde bunları kutsamışlardır. Bu inanç Türklerin, Eski Türk dininden sonra benimsedikleri İslam, Hristiyanlık, Musevilik, Budizm, Maniheizm gibi diğer dinler bünyesinde de varlığını sürdürmüştür. Türk tarihi, mitoloji ve destanlarına baktığımızda su kültünün muhtelif şekillerde Türk devlet anlayışı ve toplum hayatında çeşitli görevler üstlendiğini görürüz. Türk toplulukları suyu kutsal kabul etmekle beraber onu kendi hayatlarını düzenleyen, yardım eden, düşmanlarına karşı galip gelmesini sağlayan, hayat veren, zorluklardan kurtaran ve cezalandıran bir unsur olarak görüp adeta kendi sosyal yaşantılarının bir parçası haline getirmişlerdir. Bu makalede öncelikle evrensel olarak su kültünün sahip olduğu simgesel anlamlar ortaya konmuş, ardından bu anlamların Türk kültüründe nasıl algılandığı konusunda örnekler verilmeye çalışılmıştır.

Anahtar Sözcükler: Su kültü, Türk destanları, Türk mitolojisi, Gök Tanrı, yer-su.

\section{ABSTRACT}

The meanings attributed to the water element, which is the indispensable element of natural life, by various cultures in the world, caused water to gain a divine feature overtime and to be called "cult". This situation is also valid in applications in Turkish culture. Water cult has an important place among objects attributed to sanctity by Turkish communities. Turks believed that water resources such as river, lake, sea, stream, swamp had special powers and soul. This belief continued to exist in other religions adopted by the Turks after the religion of Gök Tanrı (Sky God). When we look at Turkish history, mythology and epics, we see that the water cult has various roles in Turkish state and social life in sundry ways. Therewithal

\footnotetext{
* Doktora Öğrencisi. İstanbul Üniversitesi, Sosyal Bilimler Enstitüsü, Genel Türk Tarihi Anabilim Dalı, İstanbul/Türkiye. E-mail: ucarhus91@gmail.com. ORCID ID: 0000-0002-3191-8768. turnitin $\square$ 
Turkish communities perceived the water cult as an element that organizes their own lives, helps them, makes them victorious against their enemies, gives life, saves them from difficulties and becomes punitive. In this article, first of all, the symbolic meanings of water cult are presented, and then it is tried to give examples of how these meanings are perceived in Turkish culture.

Keywords: Water cult, Turkish epics, Turkish mythology, Gök Tanrı, yer-su.

\section{Giriş}

Türkler, tarih sahnesine çıktıktan sonra belirli bir yerde oturmamış, doğudan batıya doğru sürekli göç ederek farklı kültürel değerlerle karşılaşıp bunların unsurlarını bünyesine katarak zenginleşmiştir (Özkul, 2015: 169). Genel olarak Türklerin hareket sahası Orta Avrupa'dan Güney Rusya ve Kuzey Sibirya ormanlarına kadar, güneyde Hindukuş dağları, doğuda İran platosu, hatta Anadolu'ya kadar uzatılabilir (ilgen, 2005: 821). Türkler bu geniş coğrafyalara yayılarak birçok toplumla münasebette bulunmuş, onların dinlerine ve kültürlerine etki etmiş aynı zamanda kendileri de bu ögelerden etkilenmişlerdir. Fakat bu etki, ne düzeyde olursa olsun mutlaka kendi öz inançlarından motifleri de kaybetmeyip yaşatmışlardır. Bunun sebebi Gök Tanrı inancının Türklerde bir arketip özelliği taşımasıdır. Böylece Eski Türk dini farklı dinler altında bile kuşaklar boyunca yaşama şansı elde etmiş, karşılaştığı din ve kültürlerin unsurlarını bu arketip üzerine yerleştirerek gelişmiştir (Zeren, 2015: 137).

Bozkır kültürü temelinde oluşan eski Türklerin dini inançlarını, tabiat kuvvetlerine inanma, atalar kültü ve Gök Tanrı inancı olarak üç grupta toplamak mümkündür. Tabiat kuvvetlerine olan inanç, eski Türk dini bünyesinde özel bir yer işgal etmektedir. Bu konuda en önemli verileri barındıran Orhun Yazıtlarında Türkler, yer, su, ağaç, orman gibi coğrafi özelliklerden kutsallık atfederek bahsetmişlerdir (Kafesoğlu, 2017: 106; Ergin, 2017: 69). Atalar kültü ise baba hukukunun inanç sahasına yansıması olarak görülür ve temelinde ölmüş büyüklere gösterilen saygı vardır. Türkler, Hunlardan bu yana atalara gösterilen saygının bir nişanesi olarak atalarının ruhuna kurbanlar sunarlardı (Kafesoğlu, 2011: 292; Schmidt, 1964: 87). Gök Tanrı ise bu üç temel grubu kapsayan en geniş ve Türk dini için en önemli unsurdur. Zira eski Türklerde bütün inanç ritüelleri Gök Tanrı inancı çerçevesinde şekillenmiştir. Çoğunlukla Şamanizm adı ile anılsa da eski çağlarda başka hiçbir kavmin inancına benzemeyen bu inanç sisteminde en yüksek varlık, inancın merkezi ve tam iktidar sahibi olan Tengri'dir (Kafesoğlu, 2011: 295). Tengri çift anlamlı olarak hem göğü hem de ulûhiyeti 
simgelediği için ilahi hâkimiyetin başlangıcının gökle alakalı olduğu kabul edilir (Turan, 2009: 66).

Gök Tanrı, yaratıcı özelliği ile eski Türk inanç sistemi içerisinde kendi mevkisini bulurken, bunun yanında dağ, ateş, ova, orman, su gibi yeryüzüne ait cisimler ve güneş, ay, yıldızlar gibi gök cisimleri gibi ögeler tıpkı Umay motifi gibi kutsallık atfedilen ve saygı duyulan unsurlar olarak göze çarpar ve onları bir "kült" olarak değerlendirmemizi gerektirir. Makalede su kültünün, bünyesinde barındırdığı simgeler ve Türk toplumlarının düşüncesinde hangi özelliklere sahip olduğu üzerinde durulmuş olup bu konu hakkında Türk tarihi ve kültüründen örnekler verilmiştir.

\section{Su Kültünün Simgeleri}

Tabiat kuvvetlerine olan inanç, neredeyse bütün halk dinlerinde mevcut bulunmaktadır ve fiziki çevrede rastlanan yanardağ, deniz, ırmak, ateş, fırtına, gök gürültüsü, yıldırım, ay, yıldızlar, güneş vb. gibi tabiat şekil ve hadiseleri karşısında duyulan hayret, korku, saygı hisleri dolayısı ile bunlara atfedilen kutsallık neticesinde kült halini almışlardır (Kafesoğlu, 1980: 42-43). Kült (tapım), dua, kurban, belirli kurallar ve yöntemlerle yapılan dinsel törenleri yani ritleri ifade eden bir terimdir. Tapım için çeşitli dinlerde belirli tapınak yerleri kullanılır ve Müslümanların Cuma namazı, Hristiyanların Pazar ayini, genellikle bütün tapımlarda ortak olan bayram günleri gibi belirli zamanlar ayrılır (Hançerlioğlu, 2000: 493). Bu durum, Müslümanlık öncesi Türklerde de geçerlidir. Ateş, mağara, tepe, göl, yersu, atalar vb. gibi unsurlar Eski Türk dininin esasını teşkil eder ve Türkler için kült hüviyetindedir (Tanyu, 1978: 28).

Bu kültler içerisinde önemli bir yere sahip olan su, hayat verici özelliği ile tabiatın en önemli unsuru olarak, çeşitli mitolojilerde ve inanışlarda karşımıza çıkar. Simgesel anlamı ile su, bütün potansiyel güçleri temsil eder ve tüm varoluşun kaynağıdır. Potansiyel gücün ve ayrışmamışığın ilkesi, evrenin içerisindeki her türlü maddenin temeli, bütün tohumların taşıyıcısıdır. Aynı zamanda dönülecek ilk özü simgeler (Eliade, 2003: 196). ifade ettiği bir diğer anlam ise doğurganlıktır. Özellikle Paleolitik çağda yaşamı ve doğurganlığın simgesi olarak dişi putların üzerine spiral şekiller çizilerek ifade edilen su, evrenin tüm tohumlarını içinde barındıran evrensel bir rahim olarak tazelik ve doğurganlıkla bağdaştırılmıştır. Sular, yaşamın içindedir ve onu canlandırır. Ayrıca suyla yıkanmak hem eski yaşamdan yeni yaşama, ölümden doğuma bir dönüş hem de ruhun madde dünyasına dönüşünü temsil eder (Eliade, 2003: 199; Akman, 2002: 1). 
Biçimi olan her şey suların üzerinde ortaya çıkar veya sulardan kopar. Bu özelliği ile suya "hylogenie"1 vasfı vermek yanlış olmaz. Karşımıza hangi dinsel yapı içerisinde çıkarsa çıksın sular her zaman aynı işlevlerini korumaktadır. Biçimleri çözmekte, değiştirmekte "günahları yıkamakta" böylece hem saflaştırıcı hem de yeniden hayat verici olmaktadır (Eliade, 1992: 183). Suyun sahip olduğu dinsel çok yönlülük tarihte pınarlar, nehirler ve ırmaklar çevresinde gelişen pek çok tapım doğurmuştur. Bu tapımlar, öncelikle suyun evrenin özünde bulunan madde olarak edindiği kutsal değerden, aynı zamanda bulunduğu yerin kutsal bir öğesi olmasından, herhangi bir akarsuya veya pınara kutsallık kazandırmasından kaynaklanmaktadır. Bu yerel kutsallıklar tamamıyla dinsel yapıya bağlı değildir. Akan su yaşar, hareketlidir, esin kaynağı olur, iyileştirici özelliktedir ve yol göstericidir. Su kaynağı veya nehir, güç, yaşam, canlılık ve süreklilik ifadesidir. Böylece bir özerklik kazanır ve kültler, öteki dinsel inanışlara karşı bağımsız bir şekilde devam eder. Bünyelerinde bulunan kutsallıkları sürekli olarak ortaya koyarlar (Eliade, 2003: 206).

Suyun kutsallığı, doğurganlığı, ilk madde özelliği, yol göstericiliği, bereket sembolü olması, canlılığı ve sürekliliği ifade etmesi² ${ }^{2}$ taşıdığı güç gibi dünya mitleri için geçerli olan simgesel özelliklerinin neredeyse hepsi Türk mitoloji anlatılarında ve Eski Türk dininin çeşitli uygulamalarında da görülür. Şüphesiz öncesi olmakla beraber ilk olarak Asya Hunlarında göze çarpan su kültüne yönelik bilgiler, Türklerin İslam dinini benimsedikten sonra da çeşitli kaynaklar tarafından anlatılagelmiştir.

\section{Türklerde Su Kültü}

Türkler, ortaya çıktıkları zamandan beri kara parçalarını susuz düşünmemiş, kara ve suyun dünyada bir bütün olarak birbirini tamamlayan unsurlar olduklarını kabul etmişlerdir (Erdemir, 2011: 822). ${ }^{3}$ Bugünkü anlamıyla "su" şekilsel anlamını Göktürkler çağında edinmeye başlamışsa da saygı duyulan bir öğe (kült) olarak kullanılması, kaynaklardan takip edilebildiği kadarıyla i̇skitlere kadar uzanmaktadır.

Göktürkler, suyu ifade etmek için "sub" kelimesini kullanmış, daha sonra "b" sesi düşerek şimdiki halini almıştır. Uygur Devleti yazıtlarında ise "sug" şeklinde geçer. Radloff'a göre Altay kültür çevresindeki Türk toplulukları da suya "sug” derlerdi. Divanu Lügat'it-Türk ve Kutadgu Bilig'te ise

\footnotetext{
${ }^{1}$ M. Eliade (2003: 196), "hylogenie" terimini evrendeki her şeyi oluşturan ilk madde, heyula olarak açıklamaktadır.

${ }^{2}$ Suyun kutsallığı ve simgeleriyle ilgili yapılmış bir çalışma için bk. (Yolcu, 2014a).

${ }^{3}$ Su kültü hakkında yapılan en güncel çalışma için bk. (Erkoç, 2020).
} 
su, "suv" olarak geçer. Hülasa su kelimesinin tarihsel gelişimini "sub, suv, sü, su" şeklinde sıralayabiliriz (Akış, 2007: 15).

Suyun Türk medeniyeti açısından mahiyetini tam olarak anlayabilmek için Orhun Yazıtlarına bakmak gerekmektedir. Orada su, "ıduk yir-sub" yani kutsal yer ve su şeklinde geçmektedir. Burada ifade edilen terim hem koruyucu ruhları hem de vatan mefhumunu içinde barındırır (Inan, 1986: 48). Türklerde kutsanmış yeri ile kutsanmış suyu ile bütün yurdun kutlu olduğu inancı hâkimdir. Suyun ve toprağın korunmadığı yer açlığın kol gezdiği yerlerdir. Yazıtlara göre halkın aç kalmaması için suyu ve toprağı koruyan hakanlar gönderilmiştir (Ulutürk, 2009: 1). Daha sonra değineceğimiz üzere Türk hakanı, Türk devletini ve kutsal yer-sularını koruduğu gibi, kutsal yer-sular da Türk hakanını ve vatanını korumakla yükümlüdür: "Atalarımızın, dedelerimizin zapt ettiği Yer-sular sahipsiz kalmasın diye...", "Türk Tanrısı ve kutsal yer ve su ruhları şöyle yapmışlar şüphesiz..." (Tekin, 2014: 27-29; Orkun, 1994: 34-35-39), şeklinde yazıtlarda geçen ifadeler, vatan anlayışı ile su kültünün karşılıklı etkileşimini anlamak açısından oldukça önemlidir. Yer-su kültünün 8. yüzyıldan itibaren Orhun Yazıtlarında bu şekilde geçmesi, ona resmi bir kült özelliğini kazandırmıştır (Dıngıl, 2012: 138).

Türklerde suya yönelik inanışlar yalnızca Orhun Yazıtlarında değil, Çin kaynaklarından İslam kaynaklarına kadar birçok eserde karşımıza çıkar. Çin kaynaklarına göre Hunlar, yılın belirli bir gününde toplanıp atalarına, Yer-su ruhlarına ve Gök Tanrı'ya kurban sunarlardı. Hunlardan sonra Orta Asya'da kurulan Türk Devletleri'nin de Yer-su'ya, Gök Tanrı'ya güneşe ve aya kurban sunduklarını Çin kaynakları belirtir (Inan, 2018: 18-19; Esin, 1978: 87). ${ }^{4}$ Köprülü, 6. ve 7. yüzyıllarda Tujueler (Gök-Türkler) ise yılın beşinci ayında kutsal saydıkları, Tamir nehri kıyısında toplanarak gök tanrısına, yere, Yer-su ruhlarına senede bir defa dini tören yaptıklarını belirtir (Köprülü, 2005: 40; Çeşmeli, 2015: 61). Ancak bu yerin bir nehir, göl ya da bir su kaynağı mı yoksa dağ veya tepe mi olduğu konusu kesinlik kazanmamıştır (Erkoç, 2020: 81-84). ${ }^{5}$ Bir başka Çin kaynağı olan Wang Yande'nin seyahatnamesinde Turfan Uygurlarında oynanan bir tür su oyunu hakkında verdiği bilgiler bazı araştırmacılar tarafından yağmur tılsımı olarak yorumlanmıştır. Ayrıca aynı seyahatnamede Qinling dağında su ve

\footnotetext{
${ }^{4}$ Bu durum Han Hanedanlığı Tarihi'nin Hsiung-nu monografisinde şöyle geçmektedir; "Yılın ilk ayında bütün beyler Ch'an Yü'nün otağında küçük bir toplantı düzenleyerek dini tören yaparlardı. Beşinci ayda Lung-ch'eng'daki büyük toplantıda atalarına göğe, yere, ruhlara ve tanrılara kurban sunarlardı." (Onat, Orsoy ve Ercilasun, 2015: 8).

${ }^{5}$ Tamir hakkındaki tartışmalar için bk. (Erkoç, 2020: 82-85).
} 
yağmur tanrısı adına dikilmiş taş üzerindeki kitabelerden de bahsedilir (İzgi, 1989: 60-65). Kuşkusuz Türklerin su kültüyle alakalı en açık bilgilerden birisi, 7. yüzyıl başlarında, Bizans tarihçisi Theophlyaktos Simokkates tarafından verilmiştir. O, Gök-Türk çevresinde Gök Tanrı'nın tek yaratıcı varlık olduğunu, bunun yanında Türklerin ateş, su gibi bazı şeylere kutsallık atfetmekle beraber ancak yer ile göğün yaratıcısı olan tanrıya taptıklarını söyler (Kafesoğlu, 1980: 63-64; Esin, 2001: 24-25; Çeşmeli 2015: 61; Roux, 1994: 115). Ayrıca Türklerin ateşi, suyu ve havayı kutlu gördükleri, toprağı da mübarek saydıkları yönünde bilgiler de verir (Erkoç, 2020: 73; Gömeç, 2011: 56).

Çin ve Bizans kaynakları dışında bazı İslam kaynaklarında da Türklerin su ile olan alakaları hakkında bilgilere rastlamak mümkündür. 8. yüzyıla ait haberlerde Dokuz Oğuzlar (Uygurlar) hakkında bilgi veren Arap gezgini Temim İbn Bahr'ın anlattığına göre Uygurlara ait Nûşecân şehrindeki bir gölün etrafına çevredeki kasaba ve köy ahalisi gelerek yılda bir kez gölün etrafını dolaşır ve bunu bir tür dinsel tören olarak icra ederlerdi (Sağır, 2006: 8). ${ }^{6}$

Su kültü ile ilgili İslam eserleri arasında en açık bilgileri ise 10. yüzyılın ünlü Arap bilgini ve gezgin İbn Fadlan'ın seyahatnamesinde buluruz. İbn Fadlan, 922 yılında ziyaret ettiği Oğuzlara dair verdiği haberlerde onların büyük tuvaletlerini yaptıktan sonra yıkanmadıklarını ve suyla ilişkilerinin olmadığını söyler. Aktardığı bilgilere göre Oğuzlar başka birinin yıkandığını görürlerse ona kızarlar ve suya bakarak bir şeyleri anlamak, sihir yapmak istediği yönünde yorumlarlar. Hatta bunu yapanlardan ceza olarak tazminat talep ederler. Bu durum Oğuzların su kültünü nasıl algıladığı konusunda fikir vermesi açısından önemlidir. Anlaşılıyor ki onlara göre su, manevi kuvvetler barındıran bir unsur ve sihir yapmak için bir araçtır. Bu sebepten ona saygıyla karışık bir korku beslerler. İbn Fadlan, Ural Nehri civarındaki Başkurt ülkesi hakkında verdiği malumatta ise onların on iki rabbi olduğunu, bunlardan en büyüklerinin gök rabbi olduğunu söylerken bu on iki rabtan birinin de su rabbı olduğunu ifade eder (Şeşen, 2019: 10-12-20; Erkoç, 2020: 85-96). Buna benzer bir ifade 11. yüzyılda İranlı coğrafyacı Gerdizî'de geçmektedir ve İrtiş Irmağı'nın kenarındaki Kimmeklerden bahsederken Kimmeklerin tanrısının su olduğunu söylemiştir (Inan, 2018: 45, Erkoç, 2020: 97). Bir başka İranlı bilgin el-Bîrûnî ise Kimek ülkesinde bir dağda bulunan bir pınara tapıldığını, ayrıca bir tatlı su gölünün yanındaki

\footnotetext{
${ }^{6}$ Zeki Velidi Togan'ın (1948: 11-14) aktardığına göre bu bilgi 10. yüzyılın başlarında eserini tamamlayan Arap Coğrafyacı íbn el-Fakih'te de "Barsghan ahalisin Isık gölü senede bir defa özel bir şekilde takdis ettikleri” şeklinde geçmektedir.
} 
taşın üzerinde bulunan, secde eden bir adamın ayakları, parmakları, avuçları ve dizlerinin izi olduğunu, Oğuz Türklerinin bunu görünce secde ettikleri yönünde bilgiler vermiştir (Erkoç, 2020: 97; Çoruhlu, 2010: 33). Yukarıda anlatılan kaynaklardaki ifadeler su kültünün Türkler tarafından nasıl algılandığı konusunda az çok bilgi edinmemizi sağlar. Ayrıca suya olan yaklaşımın Türk ülkelerini ziyaret eden gezginlerin eserlerine konu olması, bu kültün sosyal hayata da ne derece sirayet ettiği yönünde de düşünmemizi gerektirir.

İslam bilginlerinden ibn Fadlan her ne kadar açık ve faydalı bilgiler verse de anlattıklarının biraz mübalağa ile karışmış olduğunu söyleyebiliriz. Aslında suda çok vakit geçirmemek temizliğin önemsenmemesi anlamında değil, suya duyulan saygı ve onu kirletmemekle alakalı olsa gerektir. Suya atfedilen kutsallık ancak belirli kaideler ve merasimlerle kullanmayı mümkün kılıyordu (İnan, 2007: 57). Öte yandan bu kadar önemli olan bir şeyin korunup kollanması gerekiyordu. Suyun kirletilmemesiyle amaçlanan, onun kutsallığının yanında salgın hastalıkların önüne geçmek ve suyu kullanılabilir tutmak gibi ekolojik ve hijyenik sebeplerdi (Gömeç, 2011: 56; Erkoç, 2020: 100). Zira suyun, özellikle temiz suyun bozkır toplumları için ne kadar önemli olduğu malumdur.

Su kültünün etkisi sadece tarihe mâl olmuş bir inanç olarak kalmayarak günümüzdeki bazı Türk toplumlarında da etkisini sürdürmüştür. Çağdaş Şamanist Yenisey ve Altaylı Türk topluluklarına göre Yer-suların içindeki ruhlar, insanlarla beraber yaşamlarını sürdürürlerdi. Bir başka uygulamada ise Başkurtlar bir göl veya ırmakta yıkanmak istedikleri zaman elbiselerinden bir parçayı koparıp suya atarlardı. Yeni gelinleri de ırmak kenarına götürüp "babalardan kalan su, analardan kalan su" şeklinde sözler söyler ve gelinin eşyalarından bir parçayı suya atarlardı (Inan, 2007: 55-56).

Eski Türklerde tabiatta gizli kuvvetlerin varlığına inançtan bahsetmek mümkündür. Onlara göre her doğal unsurun "izi/iye" adını verdikleri bir göstergesi vardı ve bu gösterge aynı zamanda koruyucu ruh olarak görülüyordu. Bu bağlamda her suyun bir iyesi olduğuna inanılırdı. Kadim ve kutsal bir varlık olan suyu, bolluk bereket, kuvvet sembolü olarak gördükleri gibi aynı zamanda kahredici, yok edici veya koruyucu bir varlık olarak da sayarlardı (Türkyılmaz, 2013: 86). Burada bahsedilen "su" içerisinde herhangi bir birikinti, nehir, göl, deniz gibi içerisinde su bulunan her şeyi kapsamaktadır.

Eski Türklerin inancına göre bütün dünya ruhlarla doludur. Dağlar, göller, ırmaklar hep canlı nesnelerdir. Kutsallık atfedilen Alaş, Tanau, 
Hangay, Altay, Abakan, Kam, Katun, Bey, Sütgöl bölgelerindeki ırmak ve göller yalnızca coğrafi bir isim değil, aynı zamanda duyan, evlenen, çoluk çocuk sahibi olan varlıklardır (Inan, 1986: 50-51). Bütün tabiat unsurları içerisinde bir ruh barındırırdı ve bunlar hissetmek, duymak, iyilik veya kötülük yapmak gibi kişiye ait özelliklere sahipti. Aslında bu özellikler doğrudan tabiat unsurlarına ait olmayıp onların içindeki ruhlar için geçerliydi. Bu nedenle eski Türkler, bu varlıkların doğrudan kendilerini değil içlerindeki ruhları ve ruhların barındırdığı gizli güçleri kutsamışlar, buna karşı saygı, minnet, korku karışımı bir duygu beslemişlerdir. Suya atfedilen anlamların temelinde de bu duygular yatar (Türkyılmaz, 2013: 86).

"Su" ifadesi eski metinlere bakıldığında tek başına çok nadir olarak anılır. Genellikle kutsal doğa ögelerinden bahsedilirken "Yer-su" birlikte geçer. İşte Türklerin mukaddes olarak gördüğü bu Yer-suların insanların başına iyilik veya kötülük getirmek dışında bir görevi daha vardır ki o da Türk devletini ve vatanını korumaktır. Türk toplulukları devletsiz ve hakansız kaldığı zaman Türk tanrısı ile beraber Türklerin Yer-suyu, öncelikle "Türk milleti yok olmasın diye, millet olsun diye" beraberce harekete geçiyorlar, zaman zaman da Türk kağanına yardım ediyorlardı (Ögel, 2017: 45-46). Burada Türk vatanını koruyan, kağana yardım eden elbette doğrudan yer ve suların kendisi olmayıp onların içinde barındırdığı ruhlar idi. Eski Türklerde doğrudan maddeye tapma olmadığından bu unsurlar maddi değil, manevi olarak tasavvur ediliyordu (Kafesoğlu, 2011: 292).

Yukarıda verilen bilgilere ek olarak eski Türk mitolojisindeki motiflere ve su kültü ile ilgili bilgi veren kaynaklardaki uygulamalara baktığımız zaman Türk düşüncesi açısından "su”, veya Göktürk Devleti'ndeki resmi ifade ile söylenecek olursa "Yer-su"yun çeşitli özelliklere ve görevlere sahip olduğunu görürüz.

\subsection{Kurtarıcı-Yardım}

Su kültü Türk kağanları ve toplum tarafından herhangi bir mücadeleye/savaşa girişmeden önce veya devletin yok olmaya yaklaştığı durumda insanlara yardım edip onları kurtaran bir unsur olarak karşımıza çıkmaktadır. Bu konuda en aydınlatıcı örnekler Göktürk Kağanlığının yazıtlarında kendisini gösterir.

Yer-su ruhları, insanlarla ilgili pek çok şeyi düzenlemektedir. Orhun Yazıtlarında Yer-su tabiri genellikle Türklerin faydasına çalışan manevi kuvvetler olarak geçer. Böylece Göktürk çağında kutsallık atfedilen yeryüzü oluşumlarının ayrı bir ruhu olduğunun kabul edildiğini ve onların yardımcı ve iyiliksever kuvvetler olarak algılandıklarını görürüz (Çoruhlu, 
2010: 33; Kafesoğlu, 1980: 26-27). Kül Tigin yazıtının doğu yüzünün 10 ve 11. satırları ve Bilge Kağan yazıtının 10. satırlarında şöyle yazmaktadır. "Yukarıdaki Türk Tanrısı ve Türk kutsal yer ve suları şöyle yapmışlar: Türk halkı yok olmasın diye babam ilteriş Hakanı ve annem ilbilge Hatunu göğün tepesinden tutup daha yükseğe kaldırmışlar muhakkak ki" (Tekin 2014: 27-53; Orkun, 1994: 34-35). Görüldüğü gibi Türk milleti devletsiz ve hakansız kaldığı zaman, Türk tanrısı ve Türklerin kutsal yer ve suları birlikte harekete geçmişlerdir. Öte yandan Göktürk devlet anlayışına göre Türk milleti, milletsiz bir devlet olamayacağının da farkındadır. Bu sebeple kutsal güçlerin öncelikle millet yok olmasın, halk olsun diye harekete geçtiklerini yazıtlardan anlamak mümkündür (Ögel, 2017: 45).

Kutsal Yer-suların yardımı bir başka Orhun yazıtında daha karşımıza çıkar. Tonyukuk yazıtının batı yüzünün 38. satııında kavimleri itaat altına alıp düzeni sağlamak için sürekli sefer yapan vezir Tonyukuk ve askerlerinin zorlu Altay dağlarını ve îrtiş ırmağı'nı Tanrı Umay ve kutsal yer ve suların yardımıyla aştıklarını söylemektedir (Tekin, 1994: 16-17; Orkun, 1994: 113; Erkoç, 2020: 78). Gök-Türk Devleti'nin veziri tarafından söylenen bu sözler kutsal Yer-suların yardımına olan inancın devlet kademesindeki algılanış biçimi konusunda bize fikir verir.

Göktürklerin ilk köken efsanesinde de suyu koruyucu bir unsur olarak görmek mümkündür. Kurttan türeyiş mitinde eski Hunların soyundan gelen Ashina ailesinin üyeleri, Batı denizinin kuzeyinde otururken komşu bir ülkenin saldırısına uğrar ve küçük bir çocuk dışında herkes öldürülür. Bu çocuğun ise kolları ve bacakları kesilip bir bataklığa bırakılır. Buradaki bir dişi kurt tarafından besleyip büyütülür. Çocuğun ölmediğini duyan komşu ülkenin hükümdarı onu öldürmeye karar verir. Bunun üzerine kurt ve çocuk yaşadıkları bir göl kıyısının kuzeyindeki dağda bulunan bir mağaraya kaçarak kurtulurlar (Gömeç, 2011: 35; Erkoç, 2018: 54-56; Ögel, 2014: 24). Anlatılan bu mitte su kültü biraz geri planda kalmış gibi görünse de Türk kültürü için oldukça önem arz eden kurt ve mağara figürü ile birlikte bir nevi koruyuculuk görevini üstlenmiştir.

Tibetçe bir belgede kaydedilen bir Göktürk mitine göre Basmılların ülkesini geçtikten sonra kumlu bir çöle sahip büyük bir sıradağın ardında yaşayan iki boyun üzerine Göktürk hükümdarı Yama Kagan bir ordu gönderir. Ancak bu ordu dağı aşamaz ve ordudan iki asker yollarını kaybederler. Saf bir su kaynağına giden izler görürler ve bu su kaynağına vardıklarında dişi deve sürüsüyle beraber bir kadınla karşılaşırlar ve askerler saklanmak için bu kadını takip ederler (Erkoç, 2018: 72-73). Bu mitte de su 
öğesi tek başına değildir. Diğer kültlerle beraber askerlerin kurtulmasında rol oynamiştır.

Göktürk harfleriyle yazılmış bir fal kitabı olan ve 1902 tarihinde Aurel Stein tarafından bulunan Irk-Bitig'te de "sub" ifadesine rastlanır ve "bir binek atının yolda yorgunluktan bitkin halde kaldıktan sonra Tanrı'nın gücüyle dağda su ve taze ot görerek yürüyüp otu yemiş ve suyu içmiş. Böyle yapınca ölümden kurtulmuştur" şeklinde bir rüya geçer ve bu rüyanın iyiye işaret olduğu söylenir. Ögel bu vesikayı "rüyada yol ve su görmek ve böylece ölümden kurtulmak iyi yorumlanmaktadır" şeklinde yorumlamıştır (Uluç, 2016: 37; Ögel, 2014: 421).

Türk hükümdarlarının herhangi bir işe girişmeden önce Gök Tanrı'dan yardım istemek için su kültüne yönelik ritüel olarak değerlendirebilecek davranışları da kaynaklara yansımıştır. Türk oldukları düşünülen Zhou hükümdarlarının savaşa giderken yol üzerinde bulunan yerlerin Yer-sularına kurban verdikleri, yeni yurt edindikten sonra yapılan ayinlerde yere gömmek ve suda boğmak suretiyle Yer-sulara ritüeller eşliğinde hayvan kurban edip adaklar sundukları yönünde bilgiler mevcuttur (Erdemir, 2011: 823).

Tuna Bulgar Hükümdarı Kurum Han (802-814) hakkındaki kayıtlar ise Doğu Avrupa'da kurulan bir Türk devletinde de bu külte yönelik bir inanç olduğu yönünde izlenimler vermektedir. Kurum Han 813 yılındaki İstanbul kuşatmasında, önce şehrin surlarının önündeki araziyi dolaşarak askerlerine göstermiş ve mızrağını Altın Kapı'ya sapladıktan sonra bir kurban merasimine başlamıştır. Ardından denize girerek yüzünü ve ayaklarını yıkamış ve askerlerinin üzerine su serpmiştir. Askerleri de onu başlarını eğerek selamlamışlardır. Bu davranış Kurum Han'ın kendisi ve askerleri üzerinde sihri bir temizlik yapıp kötü tesirlerden korunmak şeklinde yorumlanabilir (Beşevliyev, 1945: 248-250).

Türk tarihinin ve edebiyatının en önemli eserlerinden biri olan Dede Korkut Kitabı'nda da su kültünün insanlara yardımcı olma özelliği ile ilgili örnekler mevcuttur. Salur Kazan'ın obasının yağmalanması hikâyesinde kazan obasının yağmalandığını gördükten sonra derhal yola düşer ve önüne çıkan suyla haberleşmeye başlar ve "Ordumun haberin bilür misin digil mana, kara başum kurban olsun suyum sana" diyerek insanlarının nerede olduğunu ona söylemesini isteyerek yardım diler (Ergin, 1964: 17; Ögel, 2014; 448-449). Salur Kazan'ın “Su, Allah'ın yüzünü görmüştür ve ben bu su ile konuşacağım” diyerek gaipten haber almak için bir ayna kullanan şaman, onun vasıtası ile Tanrı veya ruhlarla konuşmaktadır (Roux, 1994: 117; Ergin, 1964: 17; Yolcu, 2016: 1549; Erkoç, 2020: 88-89). Su kültü, 
birçok Dede Korkut hikâyesinde kimi zaman pınar, kimi zaman saf su şeklinde karşımıza çıkmaktadır. Zaten hikâyelerin sonunda Dede Korkut'un ettiği duaların çoğunda "kamın akan görklü suyun kurumasın" yani "taşkın akan güzel suyun kurumasın" cümlesi vardır.

Oğuz Kağan destanında ise Oğuz, Kıl-Barak kavmine karşı savaşırken Kıl-Baraklar Oğuz'un pek çok askerini öldürür ve Oğuz Kağan geri kalanları da kurtarmak için geri dönüp büyük bir ırmağın kenarına gelerek buradan karşıdaki adacığa geçer ve askerlerini kurtarır (Gündüz, 2016: 71; Togan, 1982: 25). Bu hikâyede su görüldüğü gibi düşmanlar arasında bir engel vazifesi görerek Oğuz Kağan'ı korumuştur. Aslında adacıklar eski Türklerin düşüncelerinde önemli bir yere sahiptir (Ögel, 2014: 24). Dört bir yanı sularla çevrili olan adaların savunmaya elverişli fiziksel konumuna ek olarak manevi bir anlam da yüklemiş olmaları olasıdır. Suların yardımının destandaki bir başka örneği ise; Oğuz Kağan, Urukun Karanluk Yatup adlı bölgeye geldiğinde buranın ahalisi etrafa kaçışıp arkalarında birçok ganimet bırakırlar. Ordu bir nehrin kenarına gelince bu nehrin içinde altından ve gümüşten çeşitli eşyalar görürler. Onları almak için suya girdiklerinde hiçbir şey bulamazlar. Buşı Hoca ismindeki bir yaşlı, bu ganimetlerin suyun yakınındaki bir ağaca gizlendiğini ve sudaki görüntülerin bu ganimetlerin yansıması olduğunu söyler ve böylece ganimetler bulunur (Gündüz, 2016: 68; Togan, 1982: 24).

\subsection{Yaratım-Menşe}

Su kültü, yaradılış mitlerinde yaratma eyleminin daima önemli bir öğesi olmuştur. Evrenin yaratılışı ile ilgili muhtelif din ve kültürlerde birbirine benzeyen anlatımlarda evrenin temel unsuru, diğer yapılarında menşei olarak su öne çıkmaktadır. Suyu evrenin yaratıışından önce var olan ezeli bir unsur olarak gören anlayışlar söz konusudur (Ulutürk, 2009: 1). Bu durum Türklere ait yaradılış mitlerinde de mevcuttur. Verbitskiy'nin derlediği Altay Yaradılış Destanı'nda hiçbir şey var olmadan önce Tanrı Ülgen uçsuz bucaksız sular üzerinde uçarken birden birde ortaya çıkan bir taşın üzerine oturur. Ardından suyun içinde yaşayan Ak Ana adlı ilahenin buyruğu ile yer ve göğü yaratır. Bir süre sonra su üzerinde yüzen bir toprak parçasının üzerindeki kilden de insanı yaratarak ona Erlik adını verir (Ögel, 2014: 465468; Aslan, 2007: 79-80). Radloff'un derlediği Altay Yaradılış Destanı'nda ise Tanrı ile insan suların üzerinde beraberce uçarken Tanrı, insana sulara dalıp bir avuç toprak getirmesini salık verir. Getirilen bu bir avuç toprak, Tanrı tarafından yeryüzünün yaratılmasında kullanılır (Ögel, 2014: 485486; Türkyılmaz, 2013: 85). Bu yaradılış hikâyelerinde Tanrı'nın hiçbir şekilde yalnız olmayıp ikinci derecedeki yan varlıklar ile beraber hareket et- 
tiğini görürüz (Gömeç, 2011: 104). Bu durum Türk mitolojisine has bir durum olmayıp dünyadaki birçok yaradılış miti için de geçerlidir. Eliade'nin (1992: 183) "Biçimi olan her şey suların üzerinde ortaya çıkar ve sulardan kopar” görüşüne uygun olarak Altay yaradılış destanlarında da Tanrı'nın bir yaratıcı olarak yalnız olmadığını, onunla beraber suyun daima var olduğunu gözlemleriz. Başlangıçtaki sonsuz su inancı sonraki dönemlerde okyanus, deniz, göl, ırmak gibi kavramlara kutsallık kazandırmıştır (Esin, 2018: 63). Ayrıca Tanrı Ülgen'e su altında yaşayan Ak Ana tarafından verilen yaratma ilhamından da su kültünün yaratımda ne kadar önemli bir yere sahip olduğu anlaşılabilir. Buna ek olarak suya dalmak en yüksek gizemi ve yaşamın sırrını aramak anlamlarına geldiği için insanın bir avuç toprak almak amacıyla suyun altına gitmesini de bu anlayışla yorumlamak gereklidir (Cooper, 1987: 188; Akman, 2002: 2).

Yaradılışla ilgili bir başka önemli örneği Uygur Türeyiş Destanı'nda görürüz. Cuveynî’nin anlattığına göre Uygurlar, Tula ve Selenge nehirlerinin birleştiği Kamlançu adı verilen bir yerdeki ağaçtan türemişlerdir (Cuveynî, 1988: 117). Nehirlerin birleştiği noktadaki bu yeri Ögel, "adacık” olarak açıklamıştır. (Ögel 2014: 100; Aslan 2007: 94). Destanda su kültü tek başına olmayıp ağaç motifi ile beraber zikredilmiştir. Zira bu unsurlar destanlarda genellikle birbirine bağlı bir şekilde hareket ederler. Öte yandan bu anlatıda bir başka unsur daha ön plana çıkar ki o da nehirlerin birbirine kavuştuğu yerlerdir. Bu tip yerler Türk kavimlerince kutsal sayılmışlardır (Ögel, 2014: 596).

Türklerin atasının yaratılışı hakkında bilgiler veren, Ed-Devadarî'nin Dürerü't-tîcân ve Gurer-u tevârîhi'z-zamân adlı genel tarih eserinde anlattığı yaradılış efsanesinde de suyun yaradıış̧ta ön planda olduğu anlaşılır. Bu efsaneye göre çok eski zamanlarda yeryüzüne yağan yağmurlar sellere neden olur ve Kara-Dağcı denilen mağaraya çamurları doldurur. Bu çamurlar insan kalıbına benzer ve bu kalıptaki toprak ve su güneş ışığı ile birleşir. Toprak, su ve güneş ışığının üzerine esen rüzgâr dokuz ay boyunca devam ettikten sonra insan şeklinde bir mahlûk çıkar. Bu insana "Ay-Ata" adı verilir (Inan, 1986: 21; Ögel, 2014: 520). ${ }^{7}$

Yukarıda verilen örneklere bakıldığı zaman dünya mitolojilerinde olduğu gibi İslamî dönem ve sonrasında derlenen Türk mitoloji anlatılarında başlangıçta suyun varlığı söz konusudur ama hiçbir zaman tek başına var

\footnotetext{
7 Ögel, bu efsanenin daha çok Ön Asya ve íran mitolojisi ile ilgili olduğunu, geç zamanlarda Türkler arasına girdiğini ve Türklerin efsanede geçen kişi ve yer adlarını Türkçeleştirip kendilerine mal ettiklerini belirtir. Bk. (Öğel, 2014: 522).
} 
olamaz. Su inançlarda her biçimin öncülü, her yaratımın desteğidir (Eliade, 2003: 196). Yaratıcı dünyayı tek başına yaratmamış, her zaman ikincil unsurlar devreye girmiştir. Türk mitolojisinde su, bu ikincil unsurlardan biri olarak karşımıza çıkmaktadır. Pek çok defa ise toprak, mağara, ağaç, güneş gibi önemli mitolojik ögelerle ${ }^{8}$ beraber kozmogonik ve antropogonik açıdan yaratımda yer almıştır.

\subsection{Doğum-Hayat Verme}

Dinler tarihinde su, genellikle doğumu ve yeniden doğuşu sağlayan güç olarak kabul edilmektedir (Ulutürk, 2009: 1). Bunun için Türklerde doğumla ilgili pratiklerde de su kültüne başvurulduğu yönünde örnekler görmek mümkündür. Kırgızların Manas Destanı'nın daha başlarında su ile alakalı bir motif karşımıza çıkar. Manas'ın babası Yakup Han, kendisine bir erkek çocuğu doğurmadığı için karısına, "Cıyırıcı'yı (kadını) alalı on dört yıl oldu, evliya mezarına gitmedi, elmalıkta yuvarlanmadı, kaplıcalarda (kutlu pınarlar yanında) gece yatmadı..." şeklinde veryansın eder (Radloff, 1995: 17; Ögel 2014: 458). Dede Korkut hikâyelerinden birinde de bir hatun erkek evlat istediği zaman kuru çaylara sücü döktüğünü, kara giyimli dervişlere nezir verdiğini söyler (Inan, 1986: 168). Bu sözlerden, çocuk sahibi olabilmek için su da dâhil olmak üzere çeşitli kutsal varlıklara yönelik belirli ritüeller yapılması gerektiği anlaşııı (Türkyılmaz, 2013: 89).

Oğuz Kağan Destanı'nın Uygur versiyonunda Oğuz'un yerin kızı ile evlenmesi bahsinde Oğuz, yerin kızı ile gölün ortasındaki bir ağaç kovuğunda karşılaşır ve Gün, Ay, Deniz adlı oğulları bu kızdan doğar (Gündüz, 2016: 148; Ögel 2014: 134). Ayrıca destanın Raşidüddin Fazlullah'ın derlediği İslamî versiyonunda Kıpçak Bey de yine bir nehrin ortasında bulunan adacıktaki bir ağaç kovuğunda doğmuştur. Uygurların köken efsanesinde Uygurların atası olan beş prens, iki nehrin kavşağında bulunan Kamlancu'daki kayın ağacında doğmuşlardı. Macarların ataları da bir denizin ortasındaki bataklık gibi bir yerde türemişlerdi (Ögel, 2014: 94-159; Aslan, 2007: 90).

Altay inanışlarında göğün üçüncü katında bulunan Süt-Ak-Köl (Süt gibi beyaz göl), insanların bütün hayatının ve ruhunun bağlı olduğu göl idi. Bir çocuk doğacağı zaman Tanrı Ülgen'in emri ile bu gölden ruh alınır ve çocuğa verilirdi (Ögel, 2014: 621).

Kırgız-Kazakların kısır kadınları sahrada tek başına bulunan bir ağaç, kuyu veya pınar yanında durup kurban keserler ve sabahlarlar (Akman,

\footnotetext{
${ }^{8}$ Türk mitolojisinde gök ve yer unsurları ile yaratılış ilişkisine dair bir çalışma için bk. (Yolcu, 2014b).
} 
2002: 5; Inan, 1984: 168). Kısır Tatar kadınları da bir gölün kenarına giderek dua ederlerdi. Bazı Fin-Ugor halklarında da böyle uygulamalar görülür. Kadim Karelyalılar, Mordovlar, Estonyalılar, Çeremislerde kadınların çocuk doğurmak için gittikleri bir "su ana" vardır (Eliade, 2003: 199-200). Hristiyan Çuvaşlarda da yağmur duasının kabul edilmesi için orman veya göl kenarına gitmek, suyun şifa verici özelliğine inanmak, av için ona kurban sunmak gibi uygulamalar vardır (Zeren, 2015: 152).

Yukarıda bahsi geçen örneklerde doğumla ilgili olaylarda ağaç kültü yanında su kültünün de etkisi olduğu anlaşılır. Bir taraftan kısır kadınlar su kültünden medet umarken öte yandan destan ve mitlerdeki kahramanların doğum etrafında dönen anlatılarında, su unsuru daima mevcut olmuştur (Ögel, 2014: 619; Erkoç, 2017: 55-58; Erkoç, 2018: 67-68).

Su kültünün bir başka formu ise "hayat suyu"dur. Destanlardaki hayat suyu motifi, gençleştiren, güç kuvvet kazandıran, hayat veren özellikleri ile çok fonksiyonlu ve zengin bir unsur olarak karşımıza çıkar (Aslan, 2007: 89). İyileştirir ve gençleştirir. Suyun ilk örneği "hayat suyu”dur. Hayat suyu ise güç verme özelliği ile birlikte sonsuzluğun da bir simgesidir (Eliade, 2002: 200). Hayat suyu motifi, en açık şekilde Yakutların Er-Sogotoh efsanesinde kendisini gösterir. Buna göre Er-Sogotoh'un yaşadığı evin yakınında Ağaç Hakan adında bir ağaç ve dibinde içenlerin şifa bulduğu bir hayat suyu vardır. Yaşlı inekler gelip bu sudan içince can bulur, yorgun kuşlar içince kuvvet kazanır. Er-Sogotoh bir gün savaşta kalbinden oklanıp ölünce annesi Kübey-Hatun'un kendisine verdiği hayat suyundan bir damla kalbine sıçradığında tekrar dirilir ve güçlenir (Ögel, 2014: 111-112; Aslan, 2007: 88; Çoruhlu, 2010: 127). Minusink dolaylarında derlenen bir Altay efsanesine göre ise göğün on ikinci katına kadar yükselen bir dağda bulunan kayın ağacının altındaki çukur, içenin ölmediği hayat suyuyla doludur (Ögel, 2014: 120-121). Başkurt halk destanı Ural Batur'da da hayat suyu motifi önemli bir yere sahiptir ve kuş motifi ile birlikte karşımıza çıkar. Ural Batur, kardeşi ile birlikte ölümü bulup yok etmek için yurtlarından ayrılır ve gittiği her yerde ölüme meydan okur. Canlıları ölümden kurtarmak için hayat suyunu arar. Bu suyu hüma kuşunun yardımı ile bulur ancak bir ihtiyarın sözleri ile içmekten vazgeçip dağlara serper. Böylelikle yer su ölümsüz olur (Argun, 1996: 13; Akman, 2002: 4).

Radloff'un Altaylar'da Kengi Gölü civarında tespit ettiği bir Şamanist törende hayat suyu motifinin ilginç bir uygulaması dikkat çeker. Ölünün ruhunun verebileceği zararlardan korunmak için yapılan bir törende şaman, yeni ölen bir kişinin ruhunu aşağı dünyaya götürür ve bu ruhu arala- 
rına almak istemeyen eski ölülerin ruhlarını, onlara hayat suyu vererek kandırıp yeni ölenin ruhunu aralarına bırakır (Çoruhlu, 2010: 91).

Maniheist Uygurların duvar resimlerinden birinde Türk kültürü için oldukça önemli bir simge olan Hayat Ağacı, havuz veya Yer-su ayin yeri olarak tasvir edilen bir su kaynağının içinden çıkmakta, bu su kaynağının içinde ise Türk kültüründe beylik ve kut simgesi olan kaz ve korday cinsinden bir çift kuş bulunmaktadır (Esin, 2004: 46; Zeren, 2015:141-142). Bu tasvirde suyu, hayat ağacını besleyen bir unsur olarak yorumlamak mümkündür.

\subsection{Cezalandırma-Felaket}

Kutsallık atfedilen ve toplum hayatındaki birçok konuda yardım edeceğine inanılan bir kültün cezalandırma özelliği ilginç olsa da muhtelif bilgiler bizi bu konuda düşünmeye sevk etmekte, bazı şeyleri onaylamadıklarını göstermektedir. Bu konudaki ilk örneği, kutsal Yer-su kavramının önemli bir yere sahip olduğu Orhun Yazıtlarından vermek mümkündür. Yukarıda, kutsal Yer-suların devletin ve halkın dağılmasını önlemek için yardım ettiği konusundan bahsetmiştik. Bilge Kağan Yazıtının doğu yüzünün 35. satırında yazan “... kişi besleyip doyurmuş yiğit hakanına ihanet etti. (Bu hareketi) yukarıdaki Tanrı, (aşağıdaki) kutsal Yer ve Su (ruhları ile) amcam hakanın ruhu tasvip etmedi hiç şüphesiz" şeklindeki cümleler, Göktürklerin hakana veya devlete karşı olumsuz davranışların Yer-sular tarafından da bilindiğini ve bunu onaylamadıklarını ifade eder (Tekin, 2014: 63; Erkoç, 2020: 78). ${ }^{9}$ Hükümdarlık da sağlık gibi suyun erdemlerine bağlı bir kuvvettir. Suyun bünyesinde bulunan ve kahramanlara aktarılan güç olup aynı zamanda Tanrı tarafından verilen kut, yeri geldiği zaman bu gücü kişinin aleyhine de kullanmaktadır (Eliade, 2003: 215).

6. yüzyılda Avar hakanına atfedilen ve Bizans tarihçisi Menandros tarafından kaydedilen bir antlaşma töreninde söylenenlerden su kültünün cezalandırma özelliği ile ilgili çıkarımlar yapmak mümkündür. Menandros'un anlattığına göre; Bizans ile Avarlar arasında yapılan bir anlaşmayı teyit etmek için içilen bu antta Avar hakanı "Sava üzerinde köprü kurmakla Romalılara karşı zarar vermek niyetinde isem ben Bayan, mahvolayım; bütün Avarlar mahvolsun; gök üstümüze yıkılsın, gök tanrının ateşli okları bizleri öldürsün, dağlar ve ormanlar başımıza yıkıısın; Sava suyu bizleri yutsun" demiştir (Inan, 1948: 280).

\footnotetext{
${ }^{9}$ Ögel'in (2017: 46) görüşüne göre küçüklerin büyükler gibi yaratılmadığını kabul eden Göktürk yazıtları, yer ve suların bilgisiz ve kötü (yablak) kağanların başa geçmesini engellemişler, bu yüzden onlar ya ölmüş ya da tahtlarını kaybetmiştir.
} 
Cezalandırma konusunda ilginç örneklere rastladığımız bir diğer konu ise kaynaklarda çokça geçen ve yağmur, kar, dolu yağdıran, fırtına çıkartan özelliklere sahip yada taşı hakkındaki bilgilerdir. İnanışa göre bu taşı Türk tanrısı, Türklerin büyük atasına vermiştir ve istediği zaman yağmur, kar veya dolu yağdırabilir. Bu taş her devirde büyük Türk komutanlarının veya kamlarının elinde bulunmuştur (Ayan, 2002: 625; Inan, 1986: 160). Su kültünün yağmur formunda belirmesi ile yada taşı arasında bağlantı vardır. Tüm suların anası, ilk maddesi olduğu için yağmur suyu, yeryüzündeki hayatın devam etmesi için gereken önemli bir madde idi (Ögel, 2014: 357358). Ayrıca yağmur şeklinde gökten geldiği için göğe bağlı durumdadır (Roux, 1994: 114). Yağmur, gökle olan ilişkisi nedeniyle Gök Tanrı'nın gücünü de temsil eder (Akman, 2002: 2).

Inan, Kuzey Hunlarının yönetiminde bulunan Yueban topluluğundaki bazı kâhinlerin, Rouranların saldırısına karşı çok şiddetli yağmur ve fırtına çıkarıp onların birçoğunu soğuktan kırdığını ve sellerde boğduğu yönünde Çin kaynaklarından bilgi verir (İnan, 1984: 160; Tanyu, 1968: 45). Ayrıca Asya Hunlarında su kültünün cezalandırma özelliği şeklinde düşünülebilecek bir bilgi daha vardır. M.Ö. 90 yılında Hunlar, Çinlilerin kendilerine saldırması sırasında Çin ordusunun en önemli isimlerinden biri olan Oş (Ershi) Generali Li Guangli'yi ele geçirirler. Hun Çan-yü'sü Hulugu'nun bu generale oldukça iyi davranıp yüksek rütbeler vermesi bazı Hun ileri gelenlerini rahatsız ettiği için bunlar Çan-yü'ye giderek generalin kendilerine kötü şans getirdiğini, kurban edilmesi gerektiğini söylerler. Çan-yü bu istekler karşısında çaresiz kalıp General Li Guang-li'yi idam eder. General idam edilmeden önce "öldüğüm takdirde Hunlar da yok olsun" şeklinde beddua etmiştir. İşte tam bundan sonra aylarca süren bir yağmur ve kar başlar. insanların hastalanıp hayvanların ölmesine ve kıtlığa sebep olur. Tanhu, bu felaketin generalin bedduasından olduğunu düşünmüş olacak ki onun adına bir tapınak yaptırır (Ercilasun, 2019: 105). Görüldüğü üzere Hunlara yağmur ve kar (yani su kültünün unsurları) felaket getirerek onları cezalandırmıştır. Buradaki bilgiden başka bir sonuç daha çıkarmak mümkündür ki o da Hunlar Tanrı tarafından bir şekilde cezalandırılmanın yalnızca kendi kavmi ya da kendi inançları çerçevesinde olacağını düşünmemişler, başka bir din ve kültüre mensup, Çinli bir generalin ettiği bedduadan da olabildiğince korkmuşlardır.

Bu konuda İslam kaynaklarında da çeşitli bilgiler bulmak mümkündür. ibn el-Fakih'in anlattığına göre Horasan emiri İsmail b. Ahmed, Mervezî’ye Türklere karşı savaşa çıktığını, ertesi gün tepelerinde korkunç bulutların tepelerinde toplandığını ve müthiş dolu yağdığını, ancak kendisinin iki 
rekât namaz kılması sonucunda dolunun Türk ordusunun üzerine çöktüğünü söylemiştir (Inan, 1984: 161; Togan, 1948: 14). Buradaki yağmurun bereket anlamındaki bir yağmur olmayıp, felaket getiren, orduları bozguna uğratan bir yağmur olduğu anlaşılır (Çoruhlu, 2010: 48). Türklerin, karşılaştıkları orduları yenmek adına yağmur yağdırdığına inandıkları yada taşına başvurmalarını da su kültü içerisinde yorumlamak yanlış olmaz.

Suyun felaket getirici özelliği hiç şüphesiz kendisini Tufan efsanelerinde daha açık bir şekilde gösterir. Tıpkı diğer mitolojilerde olduğu gibi Türk mitolojisinde de Tufan'da en önemli unsur sudur. Altay Türklerinin efsanelerinde anlatılanlara göre Tanrı Ülgen, Nama'ya tufan olacağını ve gemi yapmasını söyler. Bundan sonra yeryüzü sisle kaplanır ve karanlık bir hal alırken, yerin altından da sular fışkırmaya başlar. Ardından yedi gün boyunca yağmurlar yağar ve her yer suyla kaplanır. Nama'nın oğlu, yaptığı gemiden dışarı bakınca dağların dorukları dışında her yerin su ile kaplandığını görür (Akmaz, 2019: 10; Gömeç, 2011: 40). Türk kavimleri arasında anlatılan Tufan efsanelerinin çoğunluğunda su, aynı işlevi görür. Yeryüzü tamamıyla suyla kaplanır ve insanlık, seçilen bir kişiden devam eder. Burada suyun, yeryüzündeki her şeyi yuttuğu ve yok ettiği bir gerçektir. Öte yandan tufanın ifade ettiği bir diğer anlam ise yenilenmedir. Mitolojilerdeki tufan inancındaki amaç, yaradılışın meydana geldiği anın güncellenmesidir. Bunlar dünyanın ve yeni insanın doğumunun simgesel tekrarlarıdır. Ayrıca insanlığın suyun altında kalması, yeni bir insan ırkının ve yeni bir dönemin kuruluşu düşüncesiyle ilgilidir. Evren ve tarih döngüsü kavramının da simgesel anlatımıdır. Tufan, felaketle son bulan eski dönem ve yeni insanların hükmettiği yeni dönem algılarını oluşturur (Eliade, 1992: 193; Eliade, 2003: 215).

\subsection{Mezar}

Arkeolojik buluntulara ve kaynaklara yansıdığı şekilde Türk topluluklarında defin şekillerini toprağa gömme, yakma, terk etme (toprak üzerinde yapılan bir düzenleme ile çürümeye bırakma veya toprağa gömme), sergileme ve mumyalama gibi yöntemlere ayırmak mümkündür. Öte yandan suya gömmek de bu yöntemlerin arasına ilave edilir (Çoruhlu, 2004: 245-246; Tryjarski, 2012: 222). Türklerin cesetleri doğrudan doğruya suya gömdükleri konusunda diğer defin şekillerine nazaran kaynaklarda az bilgi olsa da su kültünün defin işlemlerinde çeşitli şekillerde kullanıldığını görmekteyiz. Bu konudaki ilk bilgi Glazkov kültürüne ait mezarlarda kendisini gösterir. Gumilev'e göre Hunların ataları Glazkov kültürü mensupları ile sıkı ilişki içerisindeydi. Baykal bölgesinde Glazkov devri mezarlarından anlaşıldığına göre mezarlar nehirlere doğru yönlendirilmiştir. Bu durum 
muhtemelen ölünün, ölüler ülkesine nehir yoluyla gönderileceği düşüncesi ile ilgilidir (Çoruhlu, 2019: 362)..$^{10}$

Ön Sibirya halklarına mal edilen bir defin töreni ise ölenin kayıklara yerleştirilmesi geleneğidir. Priklonskij tarafından Yakutlara mal edilen bu gelenekte Yakutlar, toprak üzerinde içinde kürek ve testi bulunan kayıkları defin amaçlı kullanmıştır. Ancak Priklonskij'in gözlemleri pek güvenilir durmamaktadır. Gurvic, Stasov ve Togan ise kayıkla defin işleminin Türkler tarafından bilinmediğini ortaya koymakla birlikte Hazarlar ve Oğuzlarda ırmak ve göllerde cenaze törenleri olduğunu söylemiştir. Bu törenlerde suya batırma söz konusu olmayıp doğrudan suya gömme şeklindedir (Tryjarski, 2012: 270).

Suya gömmek konusunda ibn Fadlan ve el-Bîrûnî gibi i̇slam yazarlarında da bilgiler bulmak mümkündür. Fadlan'ın anlattığına göre Hazar kağanı her odasında onun için bir mezar kazılmış olan yirmi odalı bir yapıya gömüldükten sonra bu yapının aşağısına Volga Nehri'nden bir yatak yönlendirilmiş ve her yer sular altında kalmıştır. Birunî’ye göre ise eski Oğuzlar, ölülerini Amu Derya, yani Ceyhun Irmağı'na atmışlardı. Ayrıca bazı araştırmacılar cesetlerin suya gömülmesinin eski bir Hun geleneği olduğunu söyler ve hatta Attila'nın, Lisa ya da Adiga Irmağı'na gömüldüğünü kabul ederler (Tryjarski, 2012: 271).

Togan, eski Hint'te hâkim olan su kültünün, ölüleri suda gömmekle günahlardan temizlenmek, suda ölmeyi şerefli bir ölüm saymak şeklinde Amu Derya ve Sir Derya bölgesindeki eski Türkler arasında da yaşadığını, Birunî̀ye dayanarak eski devirlerde Oğuzların ölülerini Ceyhun Irmağı'nda sallandırdıklarını söylemektedir. İslam devrine ait rivayetlerde Ceyhun Irmağı'nın bir günahkârın üzerinden kırk yol boyunca akarsa ölünün günahlarından temizlenip ermiş mertebesine ulaşacağı söylenmektedir. Ayrıca Oğuz menkıbelerine göre Korkut Ata'nın, Sır Derya'da bir seccade üzerinde elinde kopuzuyla ölümü beklediği anlatılmaktadır (Gökyay, 1973: 292; Sümbüllü, 2004: 68). Manas Destanı'nda ise defin merasiminde su kültü, dağ kültü ile beraber olarak 'Yakup'un oğlu genç Manas'ı Talas suyunun yanında, Sulpukor Dağı'nın başına” gömdükleri şeklinde geçmektedir (Radloff, 1995: 204). Kıpçak Türkleri arasında 11. yüzyılda, kahraman Çora Batır ile ilgili anlatılarda onun nehirde boğularak öldüğü, aynı kahramanın Dobruca Tatarları arasındaki rivayetlerinde de onun bilerek ırmağa atılmasıyla ermiş mertebesine ulaştığı anlatıır. Ayrıca Türkistan'da

\footnotetext{
${ }^{10}$ Glazkov Kültürü: Radyo karbon çalışmaları ile M.Ö. 3. binyılın ortaları ve 2. binyılın ortalarına tarihlendirilen Baykal bölgesindeki kültür. Bk. (Yıldırım 2017: 184-187).
} 
Taşkent ahalisinin ölülerini göle gömdüklerine dair bir kayıt da mevcuttur (Gökyay, 1973: 293).

Bulgaristan'da yaşayan Gagauz Türklerinde, ölümden sonra kırkıncı günde hazırlanılan sofrada ekmek ve şarap (koliva) ile birlikte bir fincan su verildiği ve bu suyun papaz tarafından ölünün canı için yere döküldüğü konusundaki bilgiler, Hristiyanlık etkisini göz ardı etmemekle birlikte, su kültünün Hristiyan Türklerin ölüm merasimlerinde de etkili olduğu izlenimi vermektedir (Zeren, 2015: 151).

Eski Türklerde kurganın tespiti, cesedin gömülmesi için en önemli adımlardan biridir. Kurganın tespitinde inançsal değerler rol oynamaktadır. Dağ tepeleri ve etekleri, ormanlık alanlar, yaylalar, ırmak yatakları ve göl kenarları defin için tercih edilen temel mekânlardandır. Defin için ulaşılması zor mekânların tercih edilmesi, atalar kültüne olan bağlılı̆ın bir gösteri olması dışında dağ, ağaç, su gibi yer su ruhlarının koruyuculuğuna olan inançla da yakından ilgilidir. Ayrıca kurganların ve ata mezarlarının her türlü saldırı ve tahribattan uzak tutulması için mezar yerini gizlemek amaçlanmıştır (Sümbüllü, 2004: 66-67).

Simgesel anlamı açısından suyun cenazelerde kullanılması, evrenin yaradılışında, hekimlikte ve büyüde ölü insanın özlemini gidermek olarak açıklanır. Ölüm, tamamen bir yok oluş ve tükeniş değil bir geri çekiliştir. Son kurtuluşu veya kozmik devire dönmeyi (birinden diğerine göç) beklerken ölünün çektiği ıstırap susuzluk olarak ifade edilir (Ulutürk, 2009: 5). Dolayısı ile suyun kullanımı bu susuzluğu giderme amacıyladır. Ayrıca yukarıda bahsettiğimiz şekliyle suyun temizlik unsuru olması sebebiyle ruhun temizliği de amaçlanmıştır.

\section{Sonuç}

Eski Türk inanışlarına göre Türkler, suya yalnızca kutsal bir unsur olarak bakıp çeşitli ritüellerle saygılarını sunmakla kalmamış, suyu yaratıma ve kendilerine yardım eden, kendi lehlerine çalışan, zaman zaman haber getiren, düşmanlarını bastıran, devletin dağılmasını önleyen, töreye karşı gelindiği zaman ceza veren bir unsur olarak da görmüşlerdir. Elbette ki bu özellikler deniz, göl, ırmak gibi maddi unsurların doğrudan kendisinin olmayıp, içinde barındırdıkları eski Türk dini etrafında şekillenen iyeleri, yani ruhlarıdır.

Türk kültürü ve mitolojisindeki motiflere baktığımız zaman tüm bu motiflerin genellikle tek başına olmayıp mağara-rüzgâr-su, su-kuş, sukurt, su-ağaç gibi diğer motiflerle beraber hareket ettiklerini görürüz. Bu nokta Türk topluluklarının doğayı algılayış biçiminin anlaşıması açısından 
oldukça önem arz etmektedir. Anlaşıldığı kadarıyla onlara göre tıpkı bozkır yaşamının gerektirdiği yardımlaşma ve dayanışma gibi doğanın kutsal addettikleri unsurları arasında da bir dayanışma mevcuttur. Bu unsurlar kültürde, destanlarda, mitolojide ve tarihte kendi özellikleri çerçevesinde birbirleriyle etkileşim halinde olmuşlardır.

Su, aynı zamanda hem fiziksel ve ruhani temizliği sağlayan bir araç hem de mezarları koruyan bir unsur olarak karşımıza çıkmaktadır. Çeşitli Türk topluluklarının suya olan saygıları destanlarda ve günlük hayattaki pratik uygulamalarda kalmamış, ölülerini suya emanet ederek veya defin merasimlerinde muhtelif şekillerde suyu kullanarak onun kutsal gücünden istifade etmeye çalışmışlardır. Üstelik su kültü, sadece Eski Türk dinini benimseyen topluluklar arasında yaşayan bir kült olmayıp Türklerin benimsedikleri diğer dinler bünyesinde de varlığını sürdürmüştür.

\section{Kaynakça}

Akış, İbrahim (2007). “Türkçede Su Kelimesinin Tarihi Gelişimi”. Türk Kültüründe Su. Haz. İbrahim Akış ve Ferhat Aslan. İstanbul: Manavgat Belediyesi Kültür Yayınları, 15-19.

Akman, Eyüp (2002). "Türk ve Dünya Kültüründe Su Kültü Üzerine Düşünceler". Kastamonu Eğitim Dergisi, 10: 1-10.

Akmaz, Gökhan (2019). "Hint, Yunan, Sümer ve Türk Mitolojilerinde Tufan Mitinin Kültürel Bellek Açısından Önemi”. DTCF Dergisi 59(2): 825843.

Alaaddin Ata Melik Cuveynî (1988). Tarih-î Cîhan Gûşa. Çev. Mürsel Öztürk. Ankara: Kültür ve Turizm Bakanlığı Yayınları.

Aslan, Ferhat (2007). "Türk Destanlarında Su Motifi". Türk Kültüründe Su. Haz. ỉbrahim Akış ve Ferhat Aslan. İstanbul: Manavgat Belediyesi Kültür Yayınları, 75-99.

Ayan, Ekrem (2002). "Türk Mitolojisinde Su Kültü ve Yada Taşı". Türkler Ansiklopedisi-3. Ankara: Yeni Türkiye Yayınları, 622-629.

Beşevliyev, V. (1945). "Proto-Bulgar Dini”. Çev. T. Acaroğlu. Belleten, 10(34): 213-263.

Cooper, J. C. (1987). Encyclopedia of Traditional Symbols. Londra: Thames and Hudson Publishing.

Çeşmeli, Ibrahim (2015). "Tarihi Kaynaklara Göre Türk Göçebelerinde Dinler, Kültler, Ritüeller ile ikonografi ( M.S. 8. Yüzyıla Kadar)”. Art-Sanat, 3: 45-96. 
Çoruhlu, Yaşar (2004). "Eski Türklerde Ölüm”. Cogito (Ölüm: Bir Topograf$y a), 40: 244-269$.

Çoruhlu, Yaşar (2010). Türk Mitolojisinin Ana Hatları. İstanbul: Kabalcı Yayınları.

Çoruhlu, Yaşar (2019). Eski Türklerin Kutsal Mezarları Kurganlar. İstanbul: Ötüken Yayınları.

Dıngıl, Fatma Aysel (2012). İslam Öncesi Türk Kültüründe Kutsallık Izafe Edilen Maddi Unsurları. Yüksek Lisans Tezi. İstanbul: İstanbul Üniversitesi Sosyal Bilimler Enstitüsü.

Eliade, Mircea (1992). Imgeler ve Simgeler. Çev. Mehmet Ali Kılıçbay. Ankara: Gece Yayınları.

Eliade, Mircea (2003). Dinler Tarihine Giriş. Çev. Lale Aslan. İstanbul: Kabalcı Yayınları.

Ercilasun, Konuralp (2019). Asya Hunları. İstanbul: Dergah Yayınları.

Erdemir, Palaz, Hatice (2011). "Eski Türklerde Su ve Su Ulaşımı”. Turkish Studies, 6(2): 819-836.

Ergin, Muharrem (1964). Dede Korkut Kitabı, Metin-Sözlük. Ankara: Türk Kültürünü Araştırma Enstitüsü Yayınları.

Ergin, Muharrem (2017). Orhun Abideleri. İstanbul: Boğaziçi Yayınları.

Ergun, Metin ve ibrahimov, Gaynislam (1996). Başkurt Halk Destanı Ural Batur. Ankara: Türksoy Yayınları.

Erkoç, Hayrettin insan (2017). "Türk Mitlerindeki Motifler (VI.-VIII. Yüzyıllar)". Journal of Old Turkish Studies, 1(1): 36-75.

Erkoç, Hayrettin İhsan (2018). "Çin ve Tibet Kaynaklarına Göre Göktürk Mitleri”. Belleten, LXXXII(293): 51-83.

Erkoç, Hayrettin insan (2020). "Bozkır Halklarında Su Kültü”. Tarih ve Kül tür Penceresinden Su ve Sağlık Uluslararası Sempozyumu. İstanbul, 69-108.

Esin, Emel (1978). İslâmiyetten Önce Türk Kültür Târîhi ve islâma Giriş. i̇stanbul: Edebiyat Fakültesi Matbaası.

Esin, Emel (2004). Osmanlidan Ortaasya'ya Türk Sanatında ikonografik Motifler. İstanbul: Kabalcı Yayınları.

Esin, Emel (2011). Türk Kozmolojisine Giriş. İstanbul: Kabalcı Yayınları.

Esin, Osman (2018). "Inanç Temelinde Suyun Yaradılış Düşüncesi ve Geleneksel Yapı Üzerindeki Etkisi”. Uluslararası Sosyal Araştırmalar Dergisi, 11(58): 61-69. 
Gökyay, Orhan, Şaik (1973). Dedem Korkudun Kitabı. İstanbul: Milli Eğitim Bakanlığı Yayınları.

Gömeç, Saadettin (2011). Şamanizm ve Eski Türk Dini. Ankara: Berikan Yayınevi.

Gündüz, Tufan (2016). Oğuz Kağan Destanı. İstanbul: Yeditepe Yayınları. Hançerlioğlu, Orhan (2000). Dünya Inançları Sözlüğü. İstanbul: Remzi Kitabevi.

İlgen, Abdülkadir (2005). "Bozkır Göçebelerinde Sosyo-Ekonomik Yapı". Sosyal Siyaset Konferansları Dergisi, 49: 817-840.

İnan, Abdülkadir (1952). "Müslüman Türklerde Şamanizm Kalıntıları". Ankara Üniversitesi ilahiyat Fakültesi Dergisi, 1(4): 19-30.

Inan, Abdülkadir (1986). Tarihte ve Bugün Şamanizm, Materyaller ve Araştırmalar. Ankara: TTK Yayınları.

Inan, Abdülkadir (2007). "Türklerde Su Kültü ile ilgili Gelenekler”. Türk Kültüründe Su. Haz. İbrahim Akış ve Ferhat Aslan. İstanbul: Manavgat Belediyesi Kültür Yayınları, 55-59.

İnan, Abdülkadir (2018). Eski Türk Dini Tarihi. Ankara: Altınordu Yayınları. İzgi, Özkan (1989). Çin Elçisi Wang Yen-te'nin Uygur Seyahatnamesi. Ankara: TTK Yayınları.

Kafesoğlu, ỉbrahim (1980). Eski Türk Dini. Ankara: Kültür Bakanlığı Yayınları.

Kafesoğlu, ibrahim (2011). Türk Millî Kültürü. İstanbul: Ötüken Yayınları.

Kafesoğlu, ibrahim (2017). Umumi Türk Tarihi Hakkında Tespitler, Görüşler, Mülahazalar. İstanbul: Ötüken Yayınları.

Köprülü, Fuat (2005). Türk Tarih-i Dinisi. Ankara: Akçağ Yayınları.

Onat, Ayşe; Orsoy Sema ve Ercilasun, Konuralp (2015). Han Hanedanlığı Tarihi Hsiung -nu (Hun) Monografisi. Ankara: TTK Yayınları.

Orkun, Namık, Hüseyin (1994). Eski Türk Yazıtları. Ankara: TDK Yayınları.

Ögel, Bahaeddin (2014). Türk Mitolojisi 1-2. Ankara: TTK Yayınları.

Ögel, Bahaeddin (2017). Türklerde Devlet Anlayışı. İstanbul Ötüken Yayınları.

Özkul, Osman (2015). "Türk Kimliğini Oluşturan Ortak Kültürel Değerler”. Emek ve Toplum Dergisi, 4(8): 166-185.

Radloff, Wilhelm (1995). Manas Destanı. Haz. Emine Gürsoy Naskali. Ankara: Türksoy Yayınları. 
Roux, Jean-Paul (1994). Türklerin ve Moğolların Eski Dini. Çev. Aykut Kazancıgil. İstanbul: işaret Yayınları.

Roux, Jean-Paul (1999). Altay Türklerinde Ölüm. Çev. Aykut Kazancıgil. İstanbul: Kabalcı Yayınları.

Sağır, Caner (2006). Temim ibn Bahr'ın Seyahatnamesi ile Mervezînin Taba-i Hayavan Eserinin Tercümesi ve Değerlendirmesi. Yüksek Lisans Tezi. İstanbul: Marmara Üniversitesi Türkiyat Araştırmaları Enstitüsü.

Schmidt, Wilhelm (1964). "Eski Türklerin Dini”. Çev. Saadettin Buluç. Türk Dili ve Edebiyatı Dergisi, 13: 75-90.

Sümbüllü, Ziya (2004). "Eski Türklerde Defin Şekilleri Üzerine Bir İnceleme”. Atatürk Üniversitesi Sosyal Bilimler Enstitüsü Dergisi, 4(2): 6172.

Şeşen, Ramazan (2019). ibn Fadlan Seyahatnamesi. İstanbul: Yeditepe Yayınları.

Tanyu, Hikmet (1968). Türklerde Taşla ilgili Inançlar. Ankara: Ankara Üniversitesi ilahiyat Fakültesi Yayınları.

Tanyu, Hikmet (1978). Türklerin Dini Tarihçesi. İstanbul: Türk Kültür Yayını.

Tekin, Talât (1994). Tonyukuk Yazıtı. Ankara: Simurg Yayınları.

Tekin, Talât (2014). Orhon Yazıtları. Ankara: TDK Yayınları.

Togan, Zeki Velidi (1948). “ibn el-Fakih'in Türkler'e Ait Haberleri”. Belleten, 48(12): 11-16.

Togan, Zeki Velidi (1982). Reşideddin Oğuznamesi, Tercüme ve Tahlili. istanbul: Enderun Kitabevi.

Tryjarski, Edward (2012). Türkler ve Ölüm. Çev. Hafize Er. İstanbul: Pinhan Yayınları.

Turan, Osman (2009). Türk Cihan Hakimiyeti Mefkûresi Tarihi. İstanbul: Ötüken Yayınları.

Türkyılmaz, Atilla (2013). “islamiyet Öncesi Türklerde Su Kültü ve Günümüze Yansımaları”. Bilim ve Kültür Uluslararası Kültür Araştırmaları Dergisi, 4: 83-100.

Uluç, Gökbey (2016). Irk Bitig. İstanbul: Kutlu Yayınevi.

Ulutürk, Muammer (2009). "Dinlerde Su Tasavvurları". Su Medeniyeti Sempozyumu Bildirileri. Konya.

Yıldırım, Elvin (2017). "Baykal Gölü Çevresindeki Kültürlerin Türklerle Olan Bağlantıları”. Türk Dünyası Araştırmaları, 117(231): 183-192. 
Yolcu, Mehmet Ali (2014a). "Kutsalın Yeniden Üretimi: Kutsal Su İnançları ve Hacıbektaş Zemzem Çeşmesi”. 21. Yüzyılda Eğitim ve Toplum, 3-8: 93-102.

Yolcu, Mehmet Ali (2014b). "Babasız Gebelik Mitleri Bağlamında Türk Mitolojisinde Gök-Yer Dikotomisi ve Ana Tanrıça Kültünün İzleri”. Hitit Üniversitesi SBE Dergisi, 7(1): 70-92.

Yolcu, Mehmet Ali (2016). "İnancın Meşrulaştırılması Bağlamında Dede Korkut’ta Kültürel Geçiş”. III. Uluslararası Türk Dünyası Kültür Kongresi "Dede Korkut ve Türk Dünyası" (izmir, 19-23 Ekim 2015), C.3. İzmir: Ege Üniversitesi Türk Dünyası Araştırmaları Enstitüsü Yayınları, 15471552.

Zeren, Ebru (2015). "Maniheist, Budist ve Hristiyan Türklerde Su ile ilgili Inançlar". 2. Turgut Reis ve Türk Denizcilik Tarihi Uluslararası Sempozyumu (Bodrum, 1-4 Kasım 2013). Muğla: Bodrum Belediyesi Yayınları, 136-158. 